\title{
Boko Haram insurgency in Nigeria as a symptom of poverty and political alienation
}

\author{
Adetoro Rasheed Adenrele \\ Dept. of Social Studies, Federal College of Education,P.M.B. 2096, Osiele, Abeokuta, $\quad$ Ogun State, Nigeria.
}

\begin{abstract}
It is almost three years ago that a group of Northern Nigerian militants that transformed from political brigandage declared a war on the country in the name of islamic jihad. This has claimed thousands of lives and millions naira worth of properties. However, a critical analysis of the mission of the group pointed to the theory of poverty and political alienation. This paper therefore examined the violent rampageous Boko Haram in Northern Nigeria from the perspectives of the current agitation for political power-shift and severe poverty in Northern Nigeria. The research tool for the study was an indepth desk survey of media reports and literature data. The paper therefore recommended a total federal restructuring and massive poverty alleviation programmes to curb Boko Haram violence and other ethno-religious crises in Nigeria.
\end{abstract}

\section{Introduction}

Boko Haram as an Arabicized-Hausa terminology which simply translates into "western education is sinful" is propagated by "jama'atul Alhul Sunnah Lidda' wati wal Jihad" sect who believed that they are committed to the Hadith of Prophet Muhammed's teachings and islamic jihad. Some analysts even regarded Boko Haram as an outgrowth of the Maitatsine riots of the 1980s and the religious/ethnic tensions that followed in the late 1990s (Johnson, 2011). According to Johnson, the founder of Boko Haram (Mohammad Yusuf) was a radical islamic cleric who trained as a Salafist (a school of thought often associated with Jihad) and was strongly influenced by 'Ibn Taymiyyah' (a fourteen century legal scholar) who preached Islamic fundamentalism. It was even reported that Yusuf set-up a mosque and an Islamic school in Maiduguri in 2002 (which attracted students from northern Nigeria and the neighbouring countries of Chad, Niger and Cameroon) to realize his aims of islamizing Nigeria (Farouk, 2012).

Before 2009, Boko Haram group did not aim to overthrow the government violently but its leader often criticized the northern Nigerian Muslims for participating in what he saw as an illegitimate, non-islamic state and preached a doctrine of withdrawal. The group gained many followers especially when its leaders continued to speak against police - brutality and political corruption with harsh government treatment (Johnson, 2011 quoting an Al-Jazeera report). The sect uprising actually rose to an apex in July 2009 when there was a reported widespread police and military suppression of Boko Haram's refusal to follow motor-bike helmet law in the Bauchi Borno, Yobe and Kano States of Nigeria. The incidence left more than 800 dead with its leader (Mohammed Yusuf) extra judicially executed. Consequently, the splintered group of Boko Haram equally called 'Yusuffiya' began to carry out a number of suicide bombings and assassinations all over northern parts of Nigeria and equally staged a prison - break in Bauchi where many of their members were located and freed more than 700 inmates in 2010. Today, the rampaging insurgence of Boko Haram had claimed more than 2000 lives and almost virtually reduced the cities of Damaturu, Maiduguri, Bauchi and Kano to ghost towns.

The questions this paper attempted to answer therefore are the following:

1. What are the theoretical frameworks that support Boko Haram insurgency?

2. To what extent has Boko Haram dismembered Nigeria?

3. What suggestions are available to safe Nigeria from total disintegration as a result of Boko Haram uprising?

\section{Theoretical frameworks that support Boko Haram}

- Islamic fundamentalist theory: Total islamization of Nigeria under the sharia law has always being the motive behind various religious riots in Northern Nigeria. This motive even dated back to the era of Jihad of Usman Dan Fodio. Indeed, Adetoro (1982) had alluded to the fact that islamization of Nigeria had been the motive behind the Jihad of Usman Dan Fodio in 1804. This was evidential from the submission of Hodgkin (1975) who claimed that the jihad of Usman Dan Fodio was "to make upon the heathen king who...make no profession of Islam, is obligatory by assent" (p. 247). Adetoro (1982) further reported that it was only the Ibadan warriors (a south western Nigeria warriors) that stopped the rampaging Fodio's Jihad conquest under the Jalumi war in 1878 around Ikirun-a south western Nigeria town. Recently, Farouk (2012) reported that Boko Haram insurgency only believed in the Quranic verse which states that "Anyone who is not governed by what Allah has revealed is among the transgressors" (Quran $6^{49}$ ), even though, it is the same Quran that says "To you be your religion and to me my religion" (Quran $\left.109^{6}\right)$. 
In a statement issued by Boko Haram group in Maiduguri on April 24, 2011, Suleiman (2011), reported that their objectives were to abolish democracy and institute sharia law as they claimed to be fighting for justice and islamisation of Nigeria. According to Suleiman, one of the group spokesmen Alzawahiri stated that the group was contented with preaching islamisation of Nigeria until 2009 when it took arms against the state because some unnamed Muslim clerics and ward heads in the North were conniving with the government to attack them following the Maiduguri crisis in July, 2009. For this reason, the spokesman submitted that:

"we would continue to fight until Islam is well established and the Muslims regain their freedom all over Nigeria. We would never be ready to compromise and we don't need amnesty. The only solution to what is happening is for the government to repent, jettison democracy, drop the constitution and adopt the laws in the Holy Qur'an (Suleiman, 2011:50).

Earlier, the group had called on the government to prosecute the police officers involved in the extra judicial killing of their leader Mohammed Yusuf and some members. They equally called for the arrest and trial of some former Northern Nigeria Governors for what they described as acts of "betrayal" because they had all along being their political thugs funded by them (the former Governors). To re-echo their interest in islamisation of Nigeria, Usigbe (2012) reported that President Jonathan was recently threatened by Boko Haram to embrace islam or resign. According to the report, a leader of the sect known as Abubakar Shekau submitted on the Youtube (Hausa language) video that:

"I call on you President Goodluck Jonathan, you should abandon this ungodly power, you should repent and for sake Christianity, including Obama, who said I have business interests in the United States" (Usigbe, 2012:1).

Indeed, this submission appears to be an extreme demand from people who feels politically alienated but finds it more convenient to turn things round under religious demand. After all, it was reported that when Prophet Mohammed (SAW) migrated from Mecca to medina in 722 A.D, he met the Jews and the Christians in medina and he never forced them to accept Islam but rather, he continued to administer judgment on them based on their faith and scriptures (Abdul, 1978).

\section{Boko Haram's Theoretical Framework}

- The Al-Qaeda/Maghreb/Al-Shabaab connection: The United Nations report was quoted to have linked Boko Haram with Al Qaeda Islamic movement (AQIM) in the Maghreb region (Nossiter, 2012). According to the report, some of the AQIM members from Nigeria and Chad had received training in Al Qaeda camps in Mali during the summer of 2011. In 2006, Al Qaeda was reported to be moving its activities to Africa. This was appreciated from the submission of Abu Azzam al-Ansari as quoted by Radin (2012) that "there is no doubt that Al-Qaeda and the holy warriors appreciate the significance of African regions for the military campaigns against the crusaders". The Emir of al-Qaeda in the Islamic Maghreb was equally reported by the same writer to have promised to provide Boko Haram with weapons, training and other support in order to expand its reach into Sub-Saharan Africa not only to gain "strategic depth" but also to "defend Muslims in Nigeria and stop the advance of a minority crusaders". Johnson (2011) even reported a kind of synchronized coordination between the Boko Haram, AQIM and Somalia's Al-Shabaab as he observed the groups focusing on suicide bombing activities and contacting the outside terrorists with an intention to relate with one another in a coordinated efforts to become a potential threat to United States and its allies. This explained the suicide bombing of United Nations House in Nigeria in August, 2011 by Boko Haram.

- The Almajiri factor: Adetoro (2010) had earlier warned that the Almajirai system of education (Qur'anic education combined with alms begging by boys of ages 7 to 15 in Northern Nigeria under half baked Mallams) could become a potential threat to Nigeria's national security if it is not harmonized with the Universal Basic Education programme in the country. It would be recalled that many of the Almajiris were immigrants from neighbouring countries of Niger and Chad republics. The Almajiris are so numerous to the extent that as many as 4,000 of such students could be in the command of one Muslim cleric (Mohammed, 2011), and when they match on the street, they look more like army of thugs. The preponderant influx of the Almajiris to northern Nigeria was therefore supported by over 1,500 unpoliced Nigerian borders with Niger and Chad republic (Fayemi, 2011). Citing Sigmund Freud psychoanalysis theory, Obioha (2009) asserts that a child that grows under the concept of Almajiri is likely to become maladjusted because according to Adetoro (2010), they are usually exposed to different forms of pressure, problems, hunger and odd jobs that are above their age. According to Shettima (2009), the Almajiris are all over the streets, very dirty, hungry, thirsty and often cause traffic hazards with calabash in their hands for alms begging. Consequently the Almajiris can be seen as the neglected, rejected and schizophrenic maladjusted youngs of Northern Nigeria that are usually with violent aggression, willing to become Boko Haram suicide bounbers on a platter of frivolous promises. As a matter of fact, the federal government of Nigeria had to raise an alarm in the Vanguard Newspaper of $24^{\text {th }}$ February, 2012 
that the Boko Haram sect were already infiltrating some northern islamic centres by indoctrinating and recruiting young pupils (the Almajiris) to expand its membership with a view to distort their mindset against the state and constitutional values. Consequently as reported in the Saturday Tribune of $14^{\text {th }}$ July, 2012, a 15 year suicide-bomber (An Almajiri) attacked the Maiduguri central mosque to detonate his bomb which killed ten people with the narrow escape of the Emir of Borno and the Borno State Deputy Speaker (Bwala, 2012).

- The poverty theory: Nigeria with more than 160 million people and nearly 350 ethnic groups, speaking 250 languages with about 50 percent Muslim, 40 percent Christian and 10 percent indigenous sects (Johnson, 2011) is very poor. According to Kester (2012), Nigeria currently ranks 158 out of 177 poor economies on the Human Development Index (HDI, 2008), despite her rich cultural endowment and abundant human and natural resources. He further quoted the International Fund for Agricultural Development (IFAD, 2007) that despite Nigeria's plentiful resources and oil wealth, poverty is widespread to the extent that the country is ranked one of the 20 poorest countries in the world. Indeed, over 70 percent of the population is classified as poor, with 35 percent living in absolute poverty (Kester, 2012.

The irony of poverty levels in Nigeria is that it portrays a tale of several countries with regional disparities. According to Omoh (2012), the Business Editor of the Vanguard Newspaper, quoting the Nigerian Bureau of Statistics (NBS), the regional poverty disparity can be appreciated in table 1 thus:

Table 1:Regional incidence of poverty by different poverty measures in Nigeria.

\begin{tabular}{|l|l|l|l|l|}
\hline \multicolumn{1}{|c|}{ Zone / Regions } & Food Poor & \multicolumn{1}{c|}{ Absolute Poor } & Relative Poor & A Dollar Poor \\
\hline North - Central & 38.6 & 59.5 & 67.5 & 59.7 \\
North - East & 51.5 & 69.0 & 76.3 & 69.1 \\
North - West & 51.8 & 70.0 & 77.7 & 70.4 \\
South - East & 41.0 & 58.7 & 67.0 & 59.2 \\
South - South & 35.5 & 55.9 & 63.8 & 56.1 \\
South - West & 25.4 & 49.2 & 59.1 & 50.1 \\
\hline
\end{tabular}

Source: Omoh (2012) quoting NBS, p. 19.

As can be seen from table 1, poverty levels are higher in the Boko Haram infected regions of the North-East, North-West and North-Central areas of Nigeria. According to the table, over 70 percent of the people in the North-West (areas of Kano, Zamfara, kebbi and Sokoto) are absolutely poor with less than 1 dollar income per day as against about 50 percent in that categories in the South-West (areas of Lagos, Ibadan, Osogbo). Equally, more than 65 percent of the people living in the North-East (areas of Maiduguri, Bauchi, Jos, Damaturu and Gombe) are absolutely poor with less than 1 dollar income per day as against about 55 percent in that categories in the South - South (areas of Benin City, Portharcourt, Uyo and Asaba). Even Tsokar (2012), in the Guardian Newspaper of $14^{\text {th }}$ February, 2012 quoted Dr Yomi Kale (The Statistician General of Nigeria's Federation) as acknowledging the fact that the North West and the North East (the most rampaging Boko Haram areas) are the two regions of the country most affected by poverty. It must even be noted that the worsening poverty level of Nigerians has been systematic, from 17.1 million people out of a population of 65 million in 1980, to 39.2 million people out of 91.5 million in 1992 and 112.47 million people out of a total population of 150 million in 2010 (Omoh, 2012). So, it may not be far from the truth to say that Boko Haram insurgency has been aggravated by systemic worsening and intolerable level of poverty in Nigeria.

- The corruption theory: The worsening intolerable level of poverty in Nigeria is caused by reckless high-level of corruption in the country. As rightly asserted by Adetoro (2012), corruption has eaten-deep into the fabrics of the Nigerian society as the country was ranked as the $90^{\text {th }}$ most corrupt nation in the world in 2001 (the Transparency International Corruption Index, 2001). Virtually all the Nigerian ministries and agencies are enmeshed in corrupt practices with the police ranked as the most corrupt among them (Adetoro, 2012). This explains why the Boko Haram insurgency is equally aggravated by law enforcement agencies' complicity. According to the Saturday Punch of $25^{\text {th }}$ February, 2012, the Nigerian General Inspector of Police and a Deputy Commissioner of Police had to be dismissed for negligence and conspiracy in the escape of one of the arrested leaders of Boko Haram. Even when it was reported that the explosives being used by the Boko Haram sects were stolen from some quarries' warehouse in Sokoto, Borno, Bauchi and Gombe States in northern Nigeria; the security men on duties were found culpable and the matters were not reported to the police (Adisa, 2012). Johnson (2011) equally reported that hundreds of extra - judicial killings and illegal public executions of Boko Haram sects by the Nigerian police as shown on the Al - Jazeera television were allowed to "go uninvestigated and unpunished" as reported by Amnesty International. It was in the pool of this injustice and pervasive corruption by the police against the Boko Haram that Utebor (2012) reported that a two-term former Head of State and President of Nigeria (General Olusegun Obasanjo) tagged the National Assembly political office 
holders as 'rogues and armed robbers' due to their corrupt impetus especially in the current oil scandal in Nigeria. This corroborates the earlier allegation of the Nigerian Central Bank Governor against Nigerian political office holders (who are less than $1 \%$ of the total population) for appropriating more than 25 percent of the national budgets to themselves (Sanusi, 2010). Consequently, it is logical to state that the reckless-popularity of corruption in Nigeria created the platform for Boko Haram's agitation for sharia law in the country.

- $\quad$ Political alienation theory: Agitations of political discomfort and imbalance from the Nigeria's northern elites are very fervent especially since the death of former President Umar Musa Yara'dua. According to Johnson (2011), many northern Nigerians view the presidency of Goodluck Jonathan, a Christian, as illegitimate arguing that it ignored the ruling party's (Peoples Democratic Party - PDP) informal power rotation which should have kept a northern Muslim as president till 2015. This was even attested to by the former National Security Adviser to President Jonathan who said that the root cause of Boko Haram was the rocking of the zoning arrangement by the PDP itself. According to the National Security Adviser, Rtd. General Andrew Owoye Azazi, the policies of the coutnry's ruling party created a climate of what is happening and manifesting in the country today. Consequently, the National Security Adviser was sacked as a result of pressures from other top echelon of PDP members from Northern Nigeria (Odebode, Fabiyi and Soriwei, 2012) and replaced by a Northerner named Sambo Dasuki.

Some seditious statements that pointed to the political discomfort of the Northern Nigerian elites were also reported in the newspapers. According to the Punch of May $16^{\text {th }}$, 2012; a former Head of State, Rtd. General Muhammed Buhari who lost in the presidential election to President Jonathan in 2011 was said to be under fire over threat of bloodshed in Nigeria over possible future election rigging (Alechenu, Fabiyi, Odesola and Adetayo, 2012). Bulari a Northern Nigerian, was quoted to have said that "if what happened in 2011 should again happen in 2015, by the grace of God, the dog and the baboon would all be soaked in blood" (Binniyat, 2012:5). Equally Alhaji Lawal Keita, another prominent northern Nigerian leader was reported to have issued another political threat to the effect that "the only condition for Nigeria to be one is for the presidency to come to the north in 2015" (Umoru, 2012:5). As a counter provocative submission however, Chief Edwin Kiagbodo Clark, a prominent Ijaw leader from the geo-political zone of the incumbent president called for the arrest of the northern leaders and their trial for sedition. It was at this point that the Northern Governors (most of whom are even from the ruling political party) did not see anything wrong in the comment of Rtd. General Buhari (the opposing presidential candidate in the last 2011 general election) but that government is being warned against 'bad future election'. (Attah and Ubabukoh, 2012). Indeed, the various political allegations and counter allegations suggest a possible support for Boko Haram as a means of overturning a perceived political alienation.

\section{Book Haram's Operational Strategies and Activities}

Since 2009, Boko Haram has been waging almost daily war on Nigeria northern territory especially against the police and military targets, media houses, churches and mosques. Aside from using stolen and self made explosives, imported guns and ammunitions, Boko Haram were reported to snatch vehicles at gunpoint's and used the less exotic ones for suicide bombings (Olawale and Adisa, 2012). Sometimes also, they ride on bicycles with riffles to attack innocent citizens and law enforcement agencies. It was even reported by Thomson (2012) citing other authorities that Boko Haram funded itself from northern governors, late Mamman Qadaffi (former Libyan leader), Bank robberies and Al-Qaeda. Their insurgencies had so far claimed more than 1,000 lives with properties worth millions of naira destroyed as can be seen in table 2 thus:

Table 2: Boko Haram's Timeline Tragic Activities

\begin{tabular}{|l|l|l|l|}
\hline S/N & \multicolumn{1}{|c|}{ DATE } & \multicolumn{1}{|c|}{ ACTIVITIES } & CONSEQUENCES \\
\hline 1 & 4 day riots in July, & $\begin{array}{l}\text { Riots across Borno, Yobe, Kano and } \\
\text { Bauchi states in north-Eastern and } \\
\text { central Nigeria over refusal to wear } \\
\text { motorbike helmets. }\end{array}$ & $\begin{array}{l}\text { Left over 800 people } \\
\text { dead. }\end{array}$ \\
\hline 2 & December, 2010 & A church in Jos bombed. & $\begin{array}{l}80 \text { worshippers } \\
\text { killed. }\end{array}$ \\
\hline 3 & June, 2011 & $\begin{array}{l}\text { Police Head quarter in Abuja } \\
\text { bombed }\end{array}$ & $\begin{array}{l}\text { About 5 people died } \\
\text { and some severely } \\
\text { injured. }\end{array}$ \\
\hline 4 & $26^{\text {th }}$ August, 2011 & $\begin{array}{l}\text { United Nation's House in Abuja } \\
\text { attacked with suicide bombing. }\end{array}$ & 20 people killed. \\
\hline 5 & $2^{\text {nd }}$ December, 2011 & A church at Abuja outskirt bombed. & 37 people died. \\
\hline 6 & $20^{\text {th }}$ January, 2012 & Kano police headquarter and & 186 people were \\
\hline
\end{tabular}




\begin{tabular}{|l|l|l|l|}
\hline & & $\begin{array}{l}\text { Immigration office attacked with } \\
\text { more than 29 explosives. }\end{array}$ & burnt to death. \\
\hline 7 & $16^{\text {th }}$ February, 2012 & $\begin{array}{l}\text { Prison break by Boko Haram in } \\
\text { Lokoja, Nigeria. }\end{array}$ & $\begin{array}{l}119 \text { prisoners } \\
\text { and 1eased } \\
\text { aarder killed. }\end{array}$ \\
\hline 8 & $29^{\text {th }}$ April, 2012 & $\begin{array}{l}\text { A car loaded with explosives } \\
\text { bombed a church compound in } \\
\text { Northern Kaduna. }\end{array}$ & $\begin{array}{l}36 \text { people were } \\
\text { killed. }\end{array}$ \\
\hline 9 & $29^{\text {th }}$ April, 2012 & $\begin{array}{l}\text { Christian worshippers at Bayero } \\
\text { University, Kano attacked with } \\
\text { sporadic shootings and bombs. }\end{array}$ & 15 people died. \\
\hline 10 & $8^{\text {th }}$ March, 2012 & $\begin{array}{l}\text { A British rescue mission against } \\
\text { Boko Haram hostages failed. }\end{array}$ & $\begin{array}{l}\text { The 2 foreigners held } \\
\text { hostage killed. }\end{array}$ \\
\hline 11 & $13^{\text {th }}$ July, 2012 & $\begin{array}{l}\text { A 15year old suicide-bomber struck } \\
\text { at Maidaguri central mosque. }\end{array}$ & 5 people died. \\
\hline
\end{tabular}

Sources: Thomson (2012) and Wikipedia, the free Encyclopedia (2012).

\section{Recommendations}

Despite federal government efforts of establishing a Joint Task Force (JTF); training about three hundred soldiers and police abroad on modern anti-terrorism combat; negotiating with Boko Haram; seeking technical assistance from United States, France, Britain, Israel and Germany etc, it appears the re-occurrence of future islamic insurgency cannot be ruled - out in Nigeria because of its historical re-occurrence since the 1804 Jihad of Usman Dan Fodio. Hence, the need to consider the following suggestions are pertinent.

- Since the comments of Northern Nigeria political elites make the issue of Boko Haram more political than religious, there is the need for people and government in Nigeria to respect the principle of party's internaldemocracy and ensure free and fair elections.

- There is the need for the federal government of Nigeria to have a stricter control of border posts in Northern Nigeria so as to avert illegal immigrants from the Maghreb region into the country. This would require the establishment of a joint border patrol between Nigeria, Chad, Niger, Cameroon and Benin republics using heavy surveillance equipment like well-equipped helicopters and satellites.

- A permanently well-structured poverty alleviation programme devoid of political patronage is urgently required in Nigeria. This requires intensification of efforts to integrate the Almajiri schools into the Universal Basic education (UBE) programmes with well-furnished classrooms, qualified teachers, purchase of uniforms and mid-day meal for the students in northern Nigeria. Equally, the existing half-baked, nonprofessional Almajiri 'mallams' (clerics and teachers) must be trained professionally and absorbed into the UBE programmes. The effort of the federal government to make electricity stable should be intensified to encourage vocational cum technical - driven poverty alleviation programmes a reality in Nigeria. This suggests that more technical colleges and vocational centres should be built by all the three - tiers of government in Nigeria and successful products of the schools should be given grants to practice their vocations.

- One the long run, there is the need for federal re-structuring in Nigeria such that each of the six geo political zones shall be controlling its own annual budget but contributing only 10 percent of it to maintain the federal agencies. The president only becomes a coordinating president with each geo - political zone headed by a vice - president supported by zonal legislatures. There should be no more legislatures at the federal level but the federal agencies are to be governed by appointed boards with equal representations from the six geo-political zones. This is to curb the gigantum corruption presently occurring at the federal level and equally giving each of the geo - political zone a true sense of belonging.

\section{Conclusion}

There is no doubt that the Boko Haram insurgency has destroyed the socio-economic fabrics of Northern Nigeria. Its origin could be traced to the era of the $19^{\text {th }}$ century Usman Dan Fodio Islamic fundamentalism with the usual demand for institutionalization of sharia law as a result of perceived socio economic injustice (wide spread poverty) and political ambition. Consequently, the need to address the corrupt federal structures and answer the recurring national questions become more pertinent in Nigeria so as to nib the rising wave of militancy in the bud. Any further delay may be catastrophic as some aggressive northern Nigeria politicians are waiting to use the 2015 general elections to dismember the country through religious and geo political sentiments. Indeed, Boko Haram lesson could go beyond Nigeria to other West African nations (Ghana inclusive) as it was reported by Thomson (2012) and Pothuraju (2012) that the United Nations' House bombing 
at Abuja (in Nigeria) by the sect pointed to its capability to 'transcend borders' and become a 'transnational' insurgence.

\section{References}

[1] Abdul, M. O. A. (1978). The Historical Origin of Islam. Lagos: Islamic Publication Bureau, pp. 33-37.

[2] Adetoro, R. A. (1982). The impact of Jalumi war (1878) on the people of Ikirun. Being a long essay submitted in partial fulfillment of the award for the Nigerian Certificate in Education (NCE) to the Department of History, Oyo (now Osun) State College of Education, Ila-Orangun, Nigeria.

[3] Adetoro, R. A. (2010). The Almajirai syndrome as a potential threat to Nigeria national security: the role of social studies education. Nigerian Journal of Social Studies, vol. XIII (1\&2): 141-150.

[4] Adetoro, R. A. (2012). 'Corruption in Nigeria's democratic governance - the case of oil subsidy scandal'. Being a paper presented at the $2^{\text {nd }}$ National Conference of the Faculty of Social Science and Management, University of Education, Winneba, Ghana held between $13^{\text {th }}-15^{\text {th }}$ March, 2012.

[5] Adisa, T. (2012). 'Security agencies uncover source of Boko Haram's explosives'. Nigerian Tribune, Tuesday $21^{\text {st }}$ February, 2012.

[6] Alechenu, J; Fabiyi, O; Odesola, T. and Adetayo, O. (2012). 'Buhari under fire over threat of bloodshed'. The Punch. Wednesday May $16^{\text {th, }} 2012$, p. 2 .

[7] Attah, D. and Ubabukoh, U. (2012). 'Shocker for Jonathan: Northern governors defend Buhari'. The Punch, Friday 18 ${ }^{\text {th }}$ May, 2012, p. 8 .

[8] Binniyat, L. (2012). '2015 ill be bloody if....Buhari'. Vanguard, Tuesday May 15 ${ }^{\text {th }}, 2012$, pp. $1 \& 5$.

[9] Bwala, J. (2012). '15-year - old bombs mosque, kills 10'. Saturday Tribune, 14 $4^{\text {th }}$ July, 2012, p. 6.

[10] Farouk, C. (2012). 'Who are Nigeria's Boko Haram Islamists'. Retrieved on $25^{\text {th }}$ April, 2012 from www.bb.com.uk/news/world_africa_13809501.

[11] Fayemi, K. (2011). 'Boko Haram can consume us'. Tell Magazine, September 26 $6^{\text {th }}, 2011$, p. 53.

[12] Hodgkin, T. (1975). Nigeria in perspective (An Historical anthology), $2^{\text {nd }}$ edition, Oxford: Oxford press, p. 247.

[13] Johnson, T. (2011). 'Boko Haram - council on foreign relations'. Retrieved on 25 ${ }^{\text {th }}$ April, 2012 from www.cfr.org/africal/bokoharam/p25739.

[14] Kester, K. O. (2012). 'National economic transformation: issues, perspective and challenges'. Being a lead paper presented at the $10^{\text {th }}$ National Conference of the School of Arts and Social Sciences, Federal College of Education, Osiele, Abeokuta, Ogun State, Nigeria held between $21^{\text {st }}-25^{\text {th }}$ May, 2012.

[15] Mohammed, S. (2011). 'FG should dialogue with Boko Haram'. Tell magazine, September 26 ${ }^{\text {th }}, 2011$, p. 55.

[16] Nossiter, A. (2012). 'Kano under siege'. The New York Times. Retrieved on $25^{\text {th }}$ April, 2012 from www.nytimes.com

[17] Obioha, E. E. (2009). Becoming a street child in poverty ridden society: a descriptive case of Kaduna metropolis, Nigeria. Retrieved on $30^{\text {th }}$ August, 2009 from journal of social science 19(1); 41-49 online.

[18] Odebode, N.; Fabiyi, O. and Soriwei, F. (2012). 'Jonathan under pressure to sack Azazi'. The Punch, Tuesday, May 1 ${ }^{\text {st }} 2012$, p. 8.

[19] Olawale, R. and Adisa, T. (2012). 'Boko Haram: Sahel joint military command invites Nigeria, as suspects demand full protection, pledge cooperation with security agents'. Sunday Tribune, $26^{\text {th }}$ February, 2012, p. 9.

[20] Omoh, G. (2012). 'How government impoverished Nigerians, poverty on rampage'. Financial Vanguard: vanguard Newspaper, $20^{\text {th }}$ February, 2012, 16-20.

[21] Pothuraju, B. (2012). 'Boko Haram's persistent threat in Nigeria'. Backgrounder. Retrieved on $27^{\text {th }}$ July, 2012 from www.idsa.in/system/files/threeatinNigeria_BabjePorthuraju.pdf uran, chapter 6, verse 49.

[22] Quran, chapter 109, verse 6.

[23] Radin, C. J. (2012). 'The threat of Boko Haram for Nigeria, Africa and beyond'. Threat matrix. A blog of the long war journal. Retrieved on $25^{\text {th }}$ April, 2012 from www.longwarjournal.org/threat.../the-threat-of-boko-haram...pdf.

[24] Sanusi, L. (2010). 'Sanusi dares NASS on $25 \%$ expenditure: says I stand by my statement' Nigerian Tribune, $2^{\text {nd }}$ December, 2010 , pp. $1 \& 4$.

[25] Saturday Punch $25^{\text {th }}$ February, 2012.

[26] Saturday Tribune $14^{\text {th }}$ July, 2012.

[27] Shettima, A. G. (2009). 'The Almajiri's syndrome: A response to General Babangida'. Retrieved on $30^{\text {th }}$ August, 2009 from www.amanaonline.com/articles/shettima/shettima_30.htm.

[28] Suleiman, T. (2011). 'Living in the shadows of Boko Haram'. Tell magazine, November $21^{\text {st }}, 2011$, p. 45.

[29] Thomson, V. (2012). 'Boko Haram and Islamic fundamentalism in Nigeria'. Global security studies, 3(3), pp. 46 - 60.

[30] Tsokar, K (2012). 'Poverty level rises as economy grows, says agency'. The Guardian, Tuesday $14^{\text {th }}$ February, 2012.

[31] Umoru, H. (2012). 'Boko Haram: Arrest Ciroma, Lawal, Kaita-Clark, challenges IBB to debate on his alleged senility, insists Northern leaders to speak out'. Vanguard, Thursday $9^{\text {th }}$ August, 2012, pp. $1 \& 5$.

[32] Usigbe, L. (2012). 'Embrace Islam, or resign, Boko Haram tells Jonathan', Nigerian Tribune, Monday $6^{\text {th }}$ August 2012 , p. 1

[33] Utebor, S. (2012). 'Rogues, armed robbers in national assembly - Obasanjo', The Punch, Wednesday $23^{\text {rd }}$ June 2012 , p. 2.

[34] Wikipedia, the free encyclopedia (2012). Boko Haram. Retrieved on $27^{\text {th }}$ July, 2012 on.wikipedia.org/wiki/Boko_Haram. 